\title{
The Prediction of LUCC in Ejina Oasis based on Markov model
}

\author{
Yaobin Wang ${ }^{1,2}$, Qi Feng ${ }^{1}$, Guangxiu Liu ${ }^{1}$, Jianhua $\mathrm{Si}^{1}$ \\ 1. The Cold and Arid Regions Environmental and Engineering Research Institute, CAS, Lanzhou, China \\ 2. Tourism Institute of Northwest Normal University, Lanzhou, China \\ yaobinwang2006@163.com, liugx@1zb.ac.cn, qifeng@1zb.ac.cn, iianhuas@1zb.ac.cn
}

\begin{abstract}
In order to predict the changes of Land Use/Cover Change (LUCC) in Ejina Oasis (EO) after water resources redistribution in Heihe River, the remote sensing images in 2002 and 2006 were selected, a new set of land use categories was developed and the Markov model was employed. Results show that: From 2010 to 2022, it still have a large change in the land use of Ejina Oasis, the area of farmland, forestland, grassland, water, construction land continue to increase, among which water is the fastest increased than the other increased land use type, the area of increase is $56.88 \mathrm{~km}^{2}$. At same time, the area of unused land continue to decline, among which saline land is the fastest reduced than others reduced land use type, the area of reduce is $23.70 \mathrm{~km}^{2}$. But the area of increment and decrement are both gradually lessen. The ecological environment of Ejina Oasis still be a state of recovery from 2010 to 2022, the proportion of farmland, forestland, grassland and water have a significant increase, while sand, saline land have a abvious decrease, and the structure of land use in $\mathbf{2 0 2 2}$ is more reasonable than it in 2010.
\end{abstract}

Keywords- Ejina Oasis, LUCC, Water Resources Redistribution in Heihe River, Markov model

\section{INTRODUCTION}

LUCC plays a vital role in regional, social and economic development and global environmental changes [1]. It is one among the most important alterations of the Earth's land surface [2]. Moreover, LUCC transformation processes have accelerated since the Second World War [3-5]. Consequently, understanding and predicting the causes, processes and consequences of LUCC have become a major challenge. In the international community, the application of LUCC can be summarized as three core issues: dynamic analysis of process, driving forces, and global and regional models of LUCC [6-9] by using RS and GIS technology. In China, it includes dynamic information access, process simulation, development trends, driving mechanism and eco-environmental effects and others [10-13]. Nevertheless, there are relatively few studies in EO. To make up this blankness and contribute to restoring the vulnerable ecosystem in EO, LUCC in EO was predicted based on the remote sensing images in 2002 and 2006 and exertion related Markov model, which could be useful for local governments to make land use policies.

\section{MATERIALS AND METHODS}

\section{A. Study area}

EO is a typical representative of oasis in arid areas. It is located in the extreme arid climate zone in China. Though located in both sides of eastern and western of Ejina River with an annual average temperature of $8.3^{\circ} \mathrm{C}$ and yearly average rainfall of only $50 \sim 70 \mathrm{~mm}$, the yearly average evaporation is over $3000 \mathrm{~mm}$. The surface water is so scarce that the run-off and groundwater become the main water resource in EO. The research scope of this paper (Fig. 1) covers the EO totally with an area of about $15,800 \mathrm{~km}^{2}$.

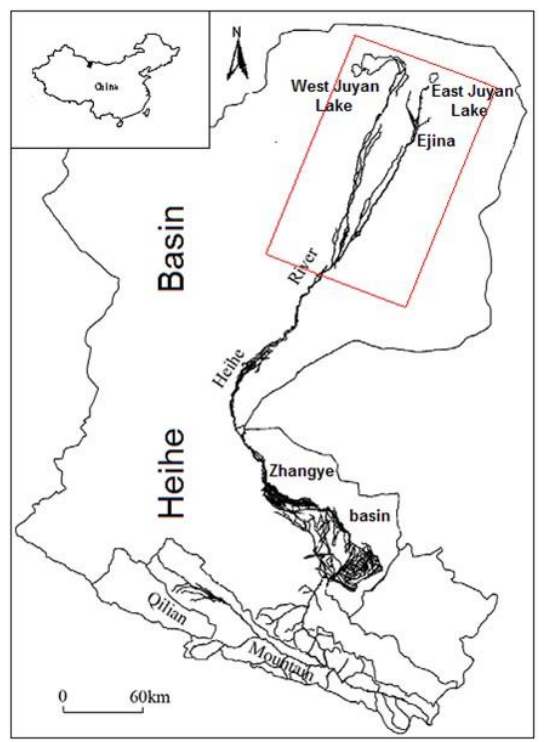

Figure1. Location of study area

\section{B. Data and Methods}

This paper adopted images in 2002 and 2006, 1:50,000 topographic map and administrative division map of the area studied which were provided by Chinese Academy of Sciences. A new set of land use categories was developed by modifying the US Geological Survey Land-use/Land Cover Classification System [14] applicable to the study area, including 6 classes and 19 sub-classes and by taking full account of these investigations in the field (TABLE I). Based on the remote sensing images and the software of ERDAS IMAGING 8.5, LUCC information of the study area was acquired. Then an

National Science Fund of China (No. 41261019, No. 91025024) 
overlay analysis of different factors' layers was done with the ARCGIS 9.0 supporting, and regional LUCC process was predicted according to all these data and the Markov model.

TABLE I. THE CLASSIFICATION OF LAND USE IN STUDY AREA

\begin{tabular}{|c|c|c|c|c|c|c|c|}
\hline \multicolumn{2}{|c|}{ Land use type } & \multicolumn{2}{|c|}{ Sub-type } & \multicolumn{2}{|c|}{ Land use type } & \multicolumn{2}{|c|}{ Sub-type } \\
\hline No & Name & No & Name & No & Name & No & Name \\
\hline \multirow{2}{*}{1} & \multirow{2}{*}{ Farmland } & 11 & $\begin{array}{l}\text { Paddy } \\
\text { field }\end{array}$ & \multirow{2}{*}{4} & \multirow{2}{*}{ Water } & 43 & $\begin{array}{l}\text { Reservoir } \\
\text { and pond }\end{array}$ \\
\hline & & 12 & Dry land & & & 44 & $\begin{array}{l}\text { Flood } \\
\text { plain }\end{array}$ \\
\hline \multirow{3}{*}{2} & \multirow{3}{*}{$\begin{array}{l}\text { Forest } \\
\text { land }\end{array}$} & 21 & $\begin{array}{c}\text { Forestry } \\
\text { land }\end{array}$ & \multirow{3}{*}{5} & \multirow{3}{*}{$\begin{array}{l}\text { Construction } \\
\text { land }\end{array}$} & 51 & Urban land \\
\hline & & 22 & $\begin{array}{c}\text { Shrub } \\
\text { land }\end{array}$ & & & 52 & $\begin{array}{c}\text { Rural } \\
\text { settlements }\end{array}$ \\
\hline & & 23 & $\begin{array}{c}\text { Sparse } \\
\text { woodland }\end{array}$ & & & 53 & $\begin{array}{c}\text { Other } \\
\text { built-up }\end{array}$ \\
\hline \multirow{3}{*}{3} & \multirow{3}{*}{ Grassland } & 31 & $\begin{array}{c}\text { High } \\
\text { coverage } \\
\text { grassland }\end{array}$ & \multirow{5}{*}{6} & \multirow{5}{*}{ Unused land } & 61 & Sand \\
\hline & & 32 & $\begin{array}{l}\text { Moderate } \\
\text { coverage } \\
\text { grassland }\end{array}$ & & & 62 & Saline land \\
\hline & & 33 & $\begin{array}{c}\text { Low } \\
\text { coverage } \\
\text { grassland }\end{array}$ & & & 63 & Gobi \\
\hline \multirow{2}{*}{4} & \multirow{2}{*}{ Water } & 41 & River & & & \multirow{2}{*}{64} & \multirow{2}{*}{$\begin{array}{l}\text { Bare rock } \\
\text { and gravel }\end{array}$} \\
\hline & & 42 & Lake & & & & \\
\hline
\end{tabular}

\section{Markov model}

Markov process is a kind of special random moving from one state to another state at each time step. A first-order Markov model is a model of such a system in which probability distribution over next state was assumed to only depend on current state (and not on previous ones) [1517].This characteristic of Markov process is appropriate to application change of land use structure, because dynamic change of land use also possesses the properties of Markov process under certain conditions: 1) within a certain region, different land use types may be transformed into each other; 2) mutual conversion process between land use types includes many incidents which are difficult to be described precisely by a special function, and 3) during study periods, average transfer state of land use structure is relatively stable and accordant with requirements of Markov Chain. The mathematics expression of Markov model is expressed as follows:

$$
S^{(0)}=\left(S_{1}^{(0)}, S_{2}{ }^{(0)} \ldots, S_{m}{ }^{(0)}\right)
$$

In this formula, $S^{(0)}$ is initial state vector of the land use.

$$
P=\left(P_{i j}\right)=\left|\begin{array}{cccc}
P_{11} & P_{12} & \ldots & P_{1 n} \\
P_{21} & P_{22} & \ldots & P_{2 n} \\
\ldots & \ldots & \ldots & \ldots \\
P_{n 1} & P_{n 2} & \ldots & P_{n n}
\end{array}\right|
$$

In this formula, $P$ is original transfer probability matrix of land use, $P_{i j}$ was probability of the ith type land transformation into the jth type land from prophase to telophase; $n$ was land use type of the study area. $P_{i j}$ should meet the following conditions:

$$
\begin{aligned}
& 0 \leq P_{i j} \leq 1 \quad(i, j=1,2,3 \ldots . . n) \\
& \sum_{i=1}^{n} P_{i j}=1 \quad(i, j=1,2,3 \ldots . n) \\
& S^{(t)}=S^{(t-1)} P=S^{(0)} P^{\Delta t}
\end{aligned}
$$

In this formula, $\Delta t$ is a state transition from the initial stepsize.

\section{RESULTS}

\section{A. The simulation and examination of Markov process}

First, by using LUCC matrix (TABLE III), the step length $4 \mathrm{a}$ of land use change matrix were calculated, and the annual matrix of land use change from 2002 to 2006 (TABLE IV) were obtained. Second, the percentage of the area of each land use type in 2002 was selected as the initial state vector. Third, Markov basic equation (the formula 5) was used to simulate the land use type in 2006. Last, did a contrast between the actual percentage of the area of each land use type in 2006 and the value of simulation (TABLE II). It can see from the TABLE II that the value of simulation and actual are very close. Error rate used the formula (6) calculate of construction land was the biggest in all land use, its value was only $0.42 \%$. And error rate of the other land use type were all smaller than it of construction land. Therefore, it was feasible use Markov process to predict the land use change in Ejina Oasis.

$E=\sqrt{\sum_{i=1}^{n}\left[\frac{\left(x_{i}-x_{i}{ }^{\prime}\right)^{2}}{x_{i}} / \sum_{i=1}^{n} x_{i}\right]} \times 100 \%$

In this formula, $x_{i}$ is the point of fitting the state variables, $x_{i}{ }^{\prime}$ is the results of fitting the state variables.

TABLE II. EXAMINATION OF LAND USE STRUCTURE BY USING MARKOV PROCESS SIMULATION $\left(\mathrm{KM}^{2}, \%\right)$

\begin{tabular}{|c|c|c|c|c|c|}
\hline Type & actual value & proportion & $\begin{array}{c}\text { Simulated } \\
\text { area }\end{array}$ & proportion & $E$ \\
\hline farmland & 49.26 & 0.31 & 48.98 & 0.31 & 0.03 \\
\hline forestland & 988.46 & 6.26 & 987.54 & 6.25 & 0.02 \\
\hline grassland & 2372.95 & 15.02 & 2371.69 & 15.01 & 0.02 \\
\hline water & 115.08 & 0.73 & 113.77 & 0.72 & 0.10 \\
\hline $\begin{array}{c}\text { Construction } \\
\text { land }\end{array}$ & 16.38 & 0.10 & 14.22 & 0.09 & 0.42 \\
\hline sand & 504.34 & 3.19 & 508.78 & 3.22 & 0.16 \\
\hline saline land & 55.29 & 0.35 & 58.46 & 0.37 & 0.34 \\
\hline Gobi & 11496.47 & 72.76 & 11491.85 & 72.73 & 0.03 \\
\hline $\begin{array}{c}\text { Bare rock } \\
\text { and gravel }\end{array}$ & 202.46 & 1.28 & 202.25 & 1.28 & 0.01 \\
\hline
\end{tabular}




\section{B. A dynamic simulation and predition in Ejina Oasis by Markov model}

According the theory of Markov model, the percentage of the area of each land use type in 2006 was selected as the initial state vector to predict the land use change in study area. And with the help of the annual matrix of land use change(TABLE IV), the software of MATLAB and Markov basic equation(the formula 5), the results of land use change prediction from 2010 to 2022 were obtained to analyze the land use change in Ejina oasis in the future(TABLE V).

It can be seen from the TABLE V : from 2010 to 2022, the areas of farmland, forestland, grassland, water and construction land are all increased, but the areas of increment are gradually lessen. For example, the value of increment of forestland is 22.12 from 2010 to 2014 , it is 22.12 from 2014 to 2018, and it is 18.96 from 2018 to 2022; the value of increment of grassland is 18.96 from 2010 to 2014 , it is 14.22 from 2014 to 2018, and it is 9.48 from 2018 to 2022 and so on. On the contrary, the area of unused land is reduced, among which the area of decrement of sub-types are gradually shrink. For example, the value of decrement of sand is 52.14 from 2010 to 2014, it is 44.24 from 2014 to 2018, and it is 37.93 from 2018 to 2022 . From 2010 to 2022 , the water is the fastest increased than the other increased land use type, the value of increase is $56.88 \mathrm{~km}^{2}$, the relative speed of increase is 1.42 . Follow are farmland and construction land, the value of increase is $14.22 \mathrm{~km}^{2}$ and $3.16 \mathrm{~km}^{2}$, the relative speed of increase is 1.26 and 1.20 respectively. And the grassland is the slowest increased type, the value of increase is $42.66 \mathrm{~km}^{2}$, the relative speed of increase is 1.02 . While the saline land is the fastest reduced than others reduced land use type, the value of reduce is $23.70 \mathrm{~km}^{2}$, the relative speed of reduce is 0.44 . Follow are sand, the value of reduce is $134.31 \mathrm{~km}^{2}$, the relative speed of reduce is 0.70 . And the area of bare rock and gravel and gobi remain a little change or unchange. In a whole, the structure of land use in 2022 is more reasonable than it in 2010 , the proportion of farmland, forestland, grassland and water have a significant increase, while sand, saline land have a abvious decrease.

\section{DISCUSSIONS AND CONCLUSIONS}

From 2010 to 2022, it still have a large change in the land use of Ejina Oasis, the area of farmland, forestland, grassland, water, construction land continue to increase, the area of unused land continue to decline. But the level of utilization and development of unused land are getting lower and lower. It is the reason that gobi, bare rock and gravel have a large proportion in the unused land type, and it is difficult to utilize and develop, while sand, saline land have a very small proportion which only have a part to be developed.

The structure of land use in 2022 is more reasonable than it in 2010, the proportion of farmland, forestland, grassland and water have a significant increase, while sand, saline land have a abvious decrease, it show ecological environment of Ejina Oasis still be a state of recovery. But the whole process of prediction has not shown the undulate characteristics of LUCC. It is the reason that condition must be follow when Markov model has been applied to predict the future trend of LUCC, which be an assumption that the influencing factors of LUCC do not change or remain a relatively stable state in a short time. And it has an uncertainty for using Markov model to predict the future trend of LUCC in a long time. Therefore, a viable and long-term recovery plan should be mapped out, which must follow strategy and experience had already be obtained in the process of the oasis recovery. Meanwhile, we should do a study about the measures and experience of the oasis recovery, discussing and comparing the measures and experience for a long time, to restore Ejina Oasis fastly and effectively.

\section{ACKNOWLEDGMENT}

This research was supported by the National Science Fund of China (No. 41261019, NO.91025024).

\section{REFERENCES}

[1] B. L. Turner II, R. H. Moss, and D. L. Skole, "Relating land use and global land-cover change: A proposal for an IGBP-HDP core project," IGBP Report No. 24 and HDP Report No. 5, Stockholm: International Geo-sphere-Biosphere Programme, 1993.

[2] E. F. Lambin, B. L. Turner II, H. J. Geist, S. B. Agbola, A Angelsen, et al, "The causes of LU and land-cover change: Moving beyond the myths," Global Environmental Change, vol. 11 , pp. 261-269, 2001.

[3] M. Antrop, "Why landscape of the past are important for the future," Landscape and Urban Planning, vol. 70, pp. 21-34, 2005.

[4] F. Ewert, M. D. A. Rounsevell, I. Reginster, M. J. Metzger, and R. Leemans, "Future scenarios of European agricultural land use. I. Estimating changes in crop productivity," Agriculture, Ecosystems and Environment, vol. 107, pp. 101-116, 2005.

[5] P. Raffaele, L. Antonio, and B. Lorenzo, "Land cover and land use change in the Italian central Apennines: A comparison of assessment methods," Applied Geography, vol. 29, pp. 35-48, 2009.

[6] X. B. Li, "A review of the international researches on landuse/land cover change," Acta Geographica Sinica, vol. 51, No. 6, pp. 553 - 557, 1996. (in Chinese)

[7] J. D. Kline, "Characterizing land use change in multidisciplinary landscape-level analyses," Agricultural and Resource Economics Review, vol. 32, No. 1, pp. 103-115, 2003.

[8] S. W. Zhang and N. Q. Tang, "Land use-cover change(LUCC) research present situation and outlook," Subtropical Agriculture Research, vol. 2, No. 3, pp. 221-225, 2006. (in Chinese )

[9] E. López, G. Bocco, M. Mendoza, A. Velázquez, and J. R. Aguirre, "Peasant emigration and land-use change at the watershed level: A GIS-based approach in Central Mexico," Agricultural Systems, vol. 90, pp. 62-78, 2006.

[10] D. F. Sun, H. Li, and F. R. Zhang, "Spatial simulation and prediction of land use and land cover using adaptive stochastic rules and landscape pattern characteristics," Transactions of the CSAE, vol. 21, No. 3, pp. 121-125, 2005. (in Chinese )

[11] Y. Zhang, G. M. Liu, H. Y. Ma, and G. X. Wang, "Changing characteristics of land-use and land-cover in the Heihe River basin," Journal of Glaciology and Geocryology, vol. 26, No. 6, pp. 740-746, 2004. (in Chinese)

[12] K. Q. Yu, Y. J. Fen, J. H. Zheng, X. J. Li, and Z. Li, "Land use changes and their ecological effects in urban-rural ecotone," Transactions of the CSAE, vol. 25, No. 3, pp. 213-218, 2009. (in Chinese)

[13] H. L. Xie, "Driving force analysis of land use changes in the typical farming - pastoral ecotone," Transactions of the CSAE, vol. 24 , No. 10 , pp. $56-62$, 2008. (in Chinese)

[14] X. Chen, "Using remote sensing and GIS to analyse land cover change and its impacts on regional sustainable development," Int. J. Remote. Sens. , vol. 23, pp. 107-124, 2002. 
[15] A.Veldkamp, E. F. Lambin, "Predicting land-use change," Agriculture, Ecosystems, and Environment., vol. 85, pp.1-6, 2001.

[16] G. Fischer, and L. X. Sun, "Model based analysis of future land-use development in China," Agriculture, Ecosystems and Environment., vol. 85, pp.163-176, 2001.
[17] B. C. Pijanowski, D. G. Brown, B. A. Shellito, et al., "Using neural networks and GIS to forecast land use changes: A land transformation model," Comput. Environ. Urban Syst., vol. 26, No. 6, pp.553-575, 2002.

TABLE III. THE CHANGE MATRIX OF LAND USE TYPES FROM 2002 TO 2006 IN STUDY AREA (KM²)

\begin{tabular}{|c|c|c|c|c|c|c|c|c|c|}
\hline $2002-2006$ & farmland & forestland & grassland & water & Construction land & sand & saline land & Gobi & $\begin{array}{c}\text { Bare rock and } \\
\text { gravel }\end{array}$ \\
\hline farmland & 41.99 & 0.12 & 0.45 & 0.38 & 0.00 & 0.07 & 0.07 & 0.00 & 0.00 \\
\hline forestland & 0.00 & 937.81 & 16.87 & 3.83 & 0.00 & 0.00 & 0.00 & 0.00 & 0.00 \\
\hline grassland & 4.44 & 27.34 & 2284.65 & 15.89 & 0.70 & 2.57 & 1.17 & 0.00 & 0.00 \\
\hline water & 0.15 & 0.47 & 2.13 & 88.70 & 0.00 & 0.00 & 0.00 & 0.00 & 0.00 \\
\hline Construction land & 0.00 & 0.10 & 0.05 & 0.00 & 14.36 & 0.11 & 0.00 & 0.00 & 0.00 \\
\hline sand & 0.00 & 22.15 & 56.29 & 0.00 & 0.00 & 496.33 & 0.00 & 1.85 & 0.00 \\
\hline saline land & 3.60 & 1.02 & 10.96 & 5.93 & 0.00 & 0.53 & 54.54 & 0.21 & 0.00 \\
\hline Gobi & 0.00 & 0.00 & 3.45 & 0.00 & 1.08 & 5.75 & 0.00 & 11490.08 & 0.00 \\
\hline Bare rock and gravel & 0.00 & 0.00 & 0.00 & 0.00 & 0.00 & 0.00 & 0.00 & 0.00 & 202.44 \\
\hline
\end{tabular}

TABLE IV. THE ANNUAL MATRIX OF LAND USE CHANGE FROM 2002 TO 2006 IN STUDY AREA

\begin{tabular}{|c|c|c|c|c|c|c|c|c|c|}
\hline $2002-2006$ & farmland & forestland & grassland & water & Construction land & sand & saline land & Gobi & Bare rock and gravel \\
\hline \begin{tabular}{|c|} 
farmland \\
\end{tabular} & 0.9937 & 0.0007 & 0.0026 & 0.0022 & 0.0000 & 0.0004 & 0.0004 & 0.0000 & 0.0000 \\
\hline forestland & 0.0000 & 0.9946 & 0.0044 & 0.0010 & 0.0000 & 0.0000 & 0.0000 & 0.0000 & 0.0000 \\
\hline grassland & 0.0005 & 0.0029 & 0.9944 & 0.0017 & 0.0001 & 0.0003 & 0.0001 & 0.0000 & 0.0000 \\
\hline water & 0.0004 & 0.0013 & 0.0058 & 0.9925 & 0.0000 & 0.0000 & 0.0000 & 0.0000 & 0.0000 \\
\hline Construction land & 0.0000 & 0.0017 & 0.0009 & 0.0000 & 0.9955 & 0.0019 & 0.0000 & 0.0000 & 0.0000 \\
\hline sand & 0.0000 & 0.0096 & 0.0244 & 0.0000 & 0.0000 & 0.9652 & 0.0000 & 0.0008 & 0.0000 \\
\hline saline land & 0.0117 & 0.0033 & 0.0357 & 0.0193 & 0.0000 & 0.0017 & 0.9276 & 0.0007 & 0.0000 \\
\hline Gobi & 0.0000 & 0.0000 & 0.0001 & 0.0000 & 0.0000 & 0.0001 & 0.0000 & 0.9998 & 0.0000 \\
\hline Bare rock and gravel & 0.0000 & 0.0000 & 0.0000 & 0.0000 & 0.0000 & 0.0000 & 0.0000 & 0.0000 & 1.0000 \\
\hline
\end{tabular}

TABLE V. PREDICTION OF LAND USE CHANGE BASED ON MARKOV MODEL IN STUdy AREA $\left(\mathrm{KM}^{2}, \%\right)$

\begin{tabular}{|c|c|c|c|c|c|c|c|c|c|}
\hline \multirow{2}{*}{ Type } & \multicolumn{2}{|c|}{2010} & \multicolumn{2}{|c|}{2014} & \multicolumn{2}{|c|}{2018} & \multicolumn{2}{|c|}{2022} & \multirow{2}{*}{ relative speed } \\
\hline & Area & proportion & Area & proportion & Area & proportion & Area & proportion & \\
\hline farmland & 55.3 & 0.35 & 60.04 & 0.38 & 64.78 & 0.41 & 69.52 & 0.44 & 1.26 \\
\hline forestland & 1015.99 & 6.43 & 1038.11 & 6.57 & 1060.23 & 6.71 & 1079.19 & 6.83 & 1.06 \\
\hline grassland & 2400.13 & 15.19 & 2419.09 & 15.31 & 2433.31 & 15.4 & 2442.79 & 15.46 & 1.02 \\
\hline water & 135.89 & 0.86 & 156.43 & 0.99 & 173.81 & 1.1 & 192.77 & 1.22 & 1.42 \\
\hline Construction land & 15.8 & 0.1 & 17.38 & 0.11 & 17.38 & 0.11 & 18.96 & 0.12 & 1.2 \\
\hline sand & 445.58 & 2.82 & 393.44 & 2.49 & 349.2 & 2.21 & 311.27 & 1.97 & 0.7 \\
\hline saline land & 42.66 & 0.27 & 31.6 & 0.2 & 25.28 & 0.16 & 18.96 & 0.12 & 0.44 \\
\hline Gobi & 11488.69 & 72.71 & 11480.79 & 72.66 & 11472.89 & 72.61 & 11464.99 & 72.56 & 1 \\
\hline Bare rock and gravel & 202.25 & 1.28 & 202.25 & 1.28 & 202.25 & 1.28 & 202.25 & 1.28 & 1 \\
\hline
\end{tabular}

